\title{
Analisis Kemampuan Pemecahan Masalah Matematika Pada Materi Garis Singgung Lingkaran Ditinjau dari Gaya Kognitif
}

\author{
Febrianti $^{*}$, Sudi Prayitno ${ }^{2}$, Syahrul Azmi², Arjudin ${ }^{2}$ \\ ${ }^{1}$ Mahasiswa Pendidikan Matematika, FKIP, Universitas Mataram, Mataram \\ 2 Pendidikan Matematika, FKIP, Universitas Mataram, Mataram \\ febifebriantiii99@gmail.com
}

Diterima: 16-12-2021; Direvisi: 30-12-2021; Dipublikasi: 30-12-2021

\begin{abstract}
This study aimed to describe students' ability in solving the tangent of the circle problems based on reflective and impulsive cognitive styles. This type of research was descriptive research. The sampling of this study were 4 students of class VIII-4 SMPN 4 Mataram who consisted of 2 reflective students and 2 impulsive students. Students with reflective cognitive style have a very good level of problem-solving ability. This is shown at the stage of understanding the problem, thinking of a plan, and carrying out the plan have done very well. Meanwhile, students with impulsive cognitive style have a level of problem-solving ability with sufficient and fewer categories. This is shown at the stage of thinking of a plan, carrying out the plan, and at the time of re-examining the results of students' work that they have not been able to do well.
\end{abstract}

Keywords: problem solving ability; cognitive style; reflective; impulsive

\begin{abstract}
Abstrak
Penelitian ini bertujuan untuk mendeskripsikan kemampuan siswa dalam menyelesaikan soal garis singgung lingkaran berdasarkan gaya kognitif reflektif dan impulsif. Jenis penelitian ini adalah penelitian deskriptif. Pengambilan sampel dalam penelitian ini adalah 4 siswa kelas VIII-4 SMPN 4 Mataram yang terdiri dari 2 siswa reflektif dan 2 siswa impulsif. Siswa dengan gaya kognitif reflektif memiliki tingkat kemampuan pemecahan masalah yang sangat baik. Hal ini ditunjukkan pada tahap memahami masalah, memikirkan rencana, dan melaksanakan rencana telah dilakukan dengan sangat baik. Sedangkan siswa dengan gaya kognitif impulsif memiliki tingkat kemampuan pemecahan masalah dengan kategori cukup dan kurang. Hal ini ditunjukkan pada tahap memikirkan suatu rencana, melaksanakan rencana, dan pada saat memeriksa kembali hasil pekerjaan siswa yang belum dapat mereka kerjakan dengan baik.
\end{abstract}

Kata Kunci: kemampuan pemecahan masalah; gaya kognitif; reflektif; impulsif

\section{PENDAHULUAN}

Matematika merupakan salah satu mata pelajaran yang menduduki peranan penting dalam pendidikan. Hal ini dapat dilihat dari diajarkannya matematika pada setiap jenjang pendidikan dari SD, SMP, SMA, hingga Perguruan Tinggi. Salah satu tujuan pembelajaran matematika disekolah menengah adalah menggunakan penalaran pada sifat, melakukan manipulasi matematika baik dalam penyederhanaan, maupun menganalisa komponen yang ada dalam pemecahan masalah dalam konteks matematika maupun diluar matematika (kehidupan nyata, ilmu, dan teknologi) yang meliputi kemampuan memahami masalah, membangun model matematika, menyelesaikan model 
dan menafsirkan solusi yang diperoleh termasuk dalam rangka memecahkan masalah dalam kehidupan sehari-hari (Kemendikbud, 2014).

Sejalan dengan hal tersebut, pemecahan masalah harus menjadi fokus dari matematika sekolah dan bahwa matematika harus diorganisir disekitar pemecahan masalah (NCTM, 2000). Karena memecahkan masalah bukan hanya sebagai tujuan dari belajar matematika, melainkan alat utama untuk belajar matematika (Soeprianto et al., 2021). Kemampuan pemecahan merupakan komponen yang sangat penting dan merupakan kemampuan dasar dalam belajar matematika sehingga perlu dikembangkan dalam pembelajaran.

Berdasarkan hasil wawancara dengan salah satu guru mata pelajaran matematika di kelas VIII SMPN 4 Mataram dapat diketahui bahwa kemampuan siswa masih rendah yaitu pada saat diberikan soal-soal yang berbentuk pemecahan masalah masih banyak siswa yang mengalami kesulitan dalam memecahkan masalah matematika dengan tahapan-tahapan yang dikemukakan para ahli, salah satunya Polya, yaitu memahami masalah, membuat rencana, melaksanakan rencana dan memeriksa kembali (Turmuzi \& Hayati, 2012). Hal ini dapat dilihat dari Tabel 1 yaitu hasil ulangan harian siswa kelas VIII SMPN 4 Mataram tahun ajaran 2019/2020.

Tabel 1. Rata-Rata Nilai Ulangan Harian Matematika Semester Genap Siswa Kelas VIII SMPN 4 Mataram Tahun Ajaran 2019/2020

\begin{tabular}{ccc}
\hline Materi Pokok & Rata-rata & Ketuntasan Klasikal (\%) \\
\hline Teorema Phytagoras & 73,20 & 44,01 \\
Lingkaran & 68,40 & 35,60 \\
Bangun Ruang Sisi Datar & 69,10 & 37,86 \\
Statistika & 76,00 & 50,81 \\
Peluang & 75,10 & 42,07 \\
\hline
\end{tabular}

Tabel 1 di atas menunjukkan bahwa nilai rata-rata ulangan harian matematika pada materi lingkaran siswa kelas VIII paling rendah diatara materi yang lain yaitu, 68,40 dengan ketuntasan klasikal 35,60\%. Hal ini terlihat dari banyaknya siswa yang mendapat nilai dibawah kriteria ketuntasan minimum (KKM) yang telah ditetapkan sekolah yaitu 75. Penyebab rendah nilai siswa adalah banyak siswa yang masih belum terbiasa dengan soal-soal pemecahan masalah dan siswa terlalu terpacu pada pencapaian hasil akhir dari penyelesaian soal sehingga kurang memperhatikan proses dan tahapantahapan dalam memperoleh hasil akhir dari soal-soal dan permasalahan yang dihadapi.

Kemampuan dan strategi yang dimiliki siswa untuk menyelesaikan soal matematika memiliki cara yag berbeda-beda. Oleh karena itu, siswa dengan karakteristik berpikir yang berbeda akan memecahkan dan menyelesaikan masalah dengan cara yang berebeda pula, sehingga hasil belajar yang dicapai oleh setiap siswa juga berbeda. Sesuai dengan pendapat Susanto, pada saat memecahkan masalah, setiap individu memiliki karakteristik khas yang tidak dimiliki oleh individu lain (Susanto, 2015). Oleh karena itu, dapat dikatakan bahwa setiap individu berbeda satu dengan yang lain. Perbedaan yang dimaksud yakni bagaimana siswa dalam menerima, mengolah dan 
mengorganisasikan informasi atau pengetahuan. Menurut Wahyuningsih et al. cara mengolah informasi ini adalah bagaian dari gaya kognitif yang menjadi salah satu penyebab adanya perbedaan kemampuan pemecahan masalah setiap siswa (Wahyuningsih et al., 2019).

Gaya kognitif merupakan karakteristik seseorang dalam memproses, menyimpan maupun menggunakan informasi untuk menanggapi suatu tugas atau berbagai jenis lingkungannya (Akbar \& Haidar, 2019). Gaya kognitif yang telah ditemukan para ahli cukup banyak macamnya, salah satunya adalah gaya kognitif yang didasarkan atas perbedaan konseptual tempo. Pakar Pendidikan Rahman yang mengklarifikasikan gaya kognitif secara konseptual tempo yaitu gaya kognitif reflektif dan gaya kognitif impulsif. Kagan menjelaskan bahwa gaya kognitif impulsif adalah siswa yang memiliki karakteristik cepat dalam menjawab masalah tetapi jawaban cenderung salah. Sedangkan siswa dengan gaya kognitif reflektif adalah siswa yang memiliki karakteristik lambat dalam menjawab tetapi jawaban yang diberikan cenderung benar (Hayuningrat \& Listiawan, 2018).

Berdasarkan uraian diatas, maka tujuan penelitian ini adalah untuk mendeskripsikan kemampuan pemecahan masalah matematika siswa kelas VIII SMPN 4 Mataram tahun ajaran 2021/2021 yang bergaya kognitif reflektif dan yang bergaya kognitif impuslif dalam menyelesaikan soal garis singgung lingkaran.

\section{METODE PENELITIAN}

Penelitian ini merupakan penelitian deskriptif yang bertujuan untuk mendeskripsikan kemampuan pemecahan masalah matematika siswa ditinjau dari gaya kognitif. Penelitian ini dilaksanakan di SMPN 4 Mataram. Subjek yang diteliti adalah siswa kelas VIII-4 di SMPN 4 Mataram. Pemilihan subjek penelitian yang memiliki gaya kognitif reflektif dan impulsif dilakukan melalui tes gaya kognitif yang berupa tes MFFT (Mathcing Familiar Figures Test) yang telah dikembangkan oleh Warli dan telah teruji validitas dan reliabilitasnya. Jumlah subjek penelitian yang dipilih adalah empat siswa, adapun kriterianya, (1) siswa reflektif diambil dari kelompok siswa reflektif yang catatan waktunya paling lama dan paling banyak benar dalam menjawab seluruh butir soal, sedangkan siswa impulsif diambil dari kelompok siswa impulsif yang catatan waktunya paling cepat dan paling banyak salah dalam menjawab seluruh butir soal, (2) siswa yang dipilih mampu berkomunikasi dengan baik saat mengemukakan pendapat/ide secara lisan maupun tulisan berdasarkan rekomendasi dari guru matematika.

Instrument yang digunakan dalam penelitian ini adalah tes gaya kognitif reflektifimpulsif yaitu Matching Familiar Figure Test (MFFT), tes kemampuan pemecahan masalah dan pedoman wawancara. Hasil tes kemampuan pemecahan masalah dan data hasil wawancara akan dianalisis, analisis kemampuan pemecahan masalah mengacu pada empat tahap pemecahan masalah menurut Polya yaitu memahami masalah, memikirkan rencana, melaksanakan rencana, dan melihat kembali. Selanjutnya analisis 
seluruh data menurut menurut Sugiyono, yaitu tahap reduksi data, tahap penyajian data, dan tahap penarikan kesimpulan (Sugiyono, 2015).

\section{HASIL DAN PEMBAHASAN}

Berdasarkan waktu (t) siswa dalam menyelesaikan masalah matematika, mulai waktu yang tercepat sampai terlama dan frekuensi jawaban siswa yang salah (f). Berdasarkan hasil tes gaya kognitif (Tes MFFT) diketahui bahwa siswa kelas VIII-4 SMPN 4 Mataram mempunyai kategori gaya kognitif yang berbeda-beda. Adapun hasil tes MFFT disajikan pada Tabel 2.

Tabel 2. Hasil Tes MFFT

\begin{tabular}{cc}
\hline Kategori & Jumlah \\
\hline Fact Accurate & 4 \\
Reflektif & 13 \\
Impulsif & 11 \\
Slow Inaccurate & 5 \\
\hline
\end{tabular}

Berdasarkan Tabel 2 menunjukkan bahwa 33 siswa kelas VIII-4 SMPN 4 Mataram yang mengikuti tes gaya kognitif (Tes MFFT) terbagi menjadi 4 bagian, yaitu 13 siswa

reflektif $(39,393 \%), 11$ siswa impulsif (33,333\%), 4 siswa cepat akurat (fast accurate) $(12,121 \%)$ dan 5 siswa lambat tidak akurat (slow inaccurate) $(15,151 \%)$. Data tersebut menunjukan bahwa siswa dengan gaya kognitif reflektif dan impulsif memiliki proporsi yang lebih besar yakni $72,726 \%$. Hal ini sesuai dengan beberapa penelitian Warli yang mengungkapkan bahwa proporsi siswa reflektif impulsif $73 \%$ lebih besar dibandingkan siswa cepat dan cermat serta siswa lambat dan tidak cermat $27 \%$. Warli mengungkapkan bahwa siswa dengan gaya kognitif reflektif impulsif memliki kontribusi yang cukup besar dibandingkan dengan siswa cepat akurat (fast accurate) dan siswa lambat tidak akurat (slow inaccurate) (Warli, 2013).

Selanjutnya, dipilih 4 subjek dengan kriteria 2 siswa bergaya kognitif reflektif dan 2 siswa bergaya kognitif impulsif. Adapun kriteria untuk menentukan 4 subjek penelitian yaitu (1) siswa reflektif diambil dari kelompok siswa reflektif yang catatan waktunya paling lama dan paling banyak benar dalam menjawab seluruh butir soal, sedangkan siswa impulsif diambil dari kelompok siswa impulsif yang catatan waktunya paling cepat dan paling banyak salah dalam menjawab seluruh butir soal, (2) siswa yang dipilih mampu berkomunikasi dengan baik saat mengemukakan pendapat/ide secara lisan maupun tulisan berdasarkan rekomendasi dari guru matematika.

Setelah menentukan 4 subjek dengan kriteria 2 siswa bergaya kognitif reflektif dan 2 siswa bergaya kognitif impulsif, kemudian dilakukan analisis tentang kemampuan pemecahan masalah siswa pada materi garis singgung lingkaran. Dari hasil tes garis singgung lingkaran tersebut, diperoleh kedua siswa reflektif memiliki tingkat kemampuan pemecahan masalah dengan kategori baik sekali. Sedangkan siswa impulsif memiliki tingkat kemampuan pemecahan masalah dengan kategori cukup dan kurang. 
Tabel 3. Kualifikasi Gaya Kognitif Siswa Dan Kategori Kemampuan Pemecahan Masalah Matematika Siswa Pada Materi Garis Singgung Lingkaran

\begin{tabular}{cccc}
\hline $\begin{array}{c}\text { Gaya Kognitif } \\
\text { Siswa }\end{array}$ & $\begin{array}{c}\text { Subjek } \\
\text { Penelitian }\end{array}$ & $\begin{array}{c}\text { Skor Pemecahan } \\
\text { Masalah Siswa }\end{array}$ & $\begin{array}{c}\text { Kategori Pemecahan } \\
\text { Masalah Siswa }\end{array}$ \\
\hline \multirow{2}{*}{ Reflektif } & $\mathrm{SR}_{1}$ & 86 & Baik Sekali \\
& $\mathrm{SR}_{2}$ & 84 & Baik Sekali \\
\multirow{2}{*}{ Impulsif } & $\mathrm{SI}_{1}$ & 56 & Cukup \\
& $\mathrm{SI}_{2}$ & 50 & Kurang \\
\hline
\end{tabular}

Berdasarkan analisis dan hasil penelitian diperoleh diperoleh bahwa skor pemecahan masalah siswa reflektif yaitu 86 dan 84 dengan kategori baik sekali. Sedangkan siswa impulsif memperoleh skor pemecahan masalah yaitu 56 dan 50 dengan kategori cukup dan kurang. Hal ini menunjukkan bahwa kemampuan pemecahan masalah matematika siswa reflektif lebih baik dibandingkan dengan siswa impulsif.

\subsection{Hasil Analisis Kemampuan Pemecahan Masalah Matematika Siswa Gaya Kognitif Reflektif}

Siswa yang bergaya kognitif reflektif yaitu siswa yang memiliki karakteristik lambat dalam menjawab masalah, tetapi cermat atau teliti sehingga jawaban yang diberikan cenderung benar. Pada tahap memahami masalah siswa reflektif dapat memahami masalah dengan baik. Pada tahap ini siswa reflektif mampu menentukan syarat yang cukup untuk dapat menyelesaikan pemecahan masalah dan dapat menuliskan apa yang diketahui dan apa yang ditanyakan dengan baik dan benar dan menjelaskan kembali soal dengan menggunakan bahasa sendiri. Hal ini sesuai dengan penelitian Puspita dan Wijayanti bahwa siswa bergaya kognitif reflektif menceritakan kembali maksud dari soal dengan benar dan menggunakan kata-katanya sendiri secara lengkap dan terurut (Puspita \& Wijayanti, 2016).

Pada tahap memikirkan rencana, siswa reflektif dalam menyelesaikan soal dapat memenuhi indikator dari memikirkan rencana yaitu dapat mencari hubungan antara hal-hal yang diketahui, hal-hal yang belum diketahui, dengan hal-hal yang ditanyakan berdasarkan fakta-fakta yang diberikan menjadi sistematis dan prosedur yang jelas dengan cara yang tepat. Siswa reflektif juga dapat menentukan rumus yang akan ia gunakan untuk menyelesaikan soal pemecahan masalah. Sesuai dengan penelitian Nasriadi yang mengatakan bahwa sebelum melakukan pemecahan masalah, subjek menentukan konsep atau operasi yang akan digunakan terlebih dahulu (Nasriadi, 2015).

Pada tahap melaksanakan rencana, siswa reflektif mampu menerapkan langkahlangkah pemecahan masalah dan rumus yang telah direncanakan dengan benar dan dapat memperoleh hasil yang benar. Siswa reflektif juga cermat atau teliti dalam menyelesaikan masalah dan membutuhkan waktu yang lama dalam menyelesaikan masalah sesuai dengan strategi yang telah direncanakan. Hal ini sesuai dengan pendapat Nasriadi subjek yang bergaya kognitif reflektif melaksanakan rencana sesuai dengan strategi yang dijelaskan pada tahap rencana pemecahan masalah. Indikator selanjutnya yang dipenuhi oleh siswa reflektif yaitu mampu menerapkan setiap rumus yang telah 
ditentukan untuk menyelesaikan masalah, serta menggunakan keterampilan algoritma dan perhitungan dalam menyelesaikan masalah (Nasriadi, 2015).

Pada tahap terakhir yaitu tahap melihat kembali, siswa reflektif hanya menuliskan kesimpulan yang diperoleh namun tidak melakukan pengecekan jawaban. Akan tetapi kedua subjek mampu menjelaskan bagaimana cara mereka memeriksa kembali jawaban mereka pada saat wawancara dengan bahasa mereka sendiri. Dengan demikian dapat disimpulkan bahwa siswa reflektif dapat memeriksa jawaban mereka sendiri dengan menggunakan unsur-unsur yang diketahui.

\subsection{Hasil Analisis Kemampuan Pemecahan Masalah Matematika Siswa Gaya Kognitif Impulsif}

Siswa yang bergaya kognitif impulsif yaitu siswa yang memiliki karakteristik cepat dalam menjawab masalah, tetapi tidak cermat atau tidak teliti sehingga jawaban yang diberikan cenderung salah. Pada tahap memahami masalah siswa impulsif mampu menuliskan apa yang diketahui dari soal tetapi tidak menuliskan dengan lengkap, menuliskan apa yang ditanyakan pada soal, dan ketika siswa impulsif diminta menjelaskan kembali soal dengan menggunakan bahasa mereka sendiri, siswa impulsif hanya menjelaskan kembali soal dengan bahasa soal atau hanya mengulang membaca soal. Hal ini sesuai dengan Puspita dan Wijayanti bahwa siswa bergaya kognitif impulsif menceritakan kembali maksud dari soal dengan benar dan menggunakan bahasa yang sama dengan soal untuk kedua soal yang diberikan (Puspita \& Wijayanti, 2016).

Pada tahap memikirkan rencana, siswa impulsif cenderung mampu menentukan rencana penyelesaian dengan benar. Siswa impulsif mampu menyelesaikan soal dengan menuliskan indikator dari memikirkan rencana yaitu siswa impulsif dapat mencari hubungan antara hal-hal yang diketahui, hal-hal yang belum diketahui, dan hal-hal yang ditanyakan tetapi tidak menuliskannya pada lembar jawaban, siswa impulsif langsung menuliskannya saat disubstitusikan kedalam rumus. Siswa impulsif juga dapat menuliskan rumus yang digunakan untuk menyelesaikan soal tetapi masih ada kekeliruan saat menuliskan rumus, bahkan ada salah satu siswa impulsif yang tidak menuliskan rumus dan langsung ke perhitungan.

Pada tahap melaksanakan rencana, siswa impulsif belum mampu melaksanakannya dengan baik yaitu siswa impulsif tidak cermat atau teliti dalam menyelesaikan masalah dan membutuhkan waktu yang relatif singkat dalam menyelesaikan masalah yang diberikan. Hal ini ditunjukkan pada saat mengerjakan soal siswa bergaya kognitif impulsif mengerjakan soal dengan alur yang tidak tepat, sehingga jawaban yang dikerjakan cenderung salah. Hal ini sejalan dengan pendapat Muniroh et al. bahwa siswa impulsif tidak memaksimalkan waktu yang disediakan dan cenderung cepat dalam mengerjakan tes pemecahan masalah (Muniroh et al., 2020). Faradillah juga menyatakan bahwa siswa dengan gaya kognitif impulsif merupakan siswa yang cepat dalam mengerjakan permasalahan tetapi lemah dalam mengerti suatu permasalahan sehingga jawaban cenderung salah (Faradillah, 2014). 
Pada tahap melihat kembali, siswa hanya mampu menuliskan kesimpulan dari jawaban seperti mencocokkan hasil yang diperoleh dengan hal yang ditanya tetapi kurang tepat karena hasil yang diperoleh salah. Namun terdapat siswa impulsif yang tidak menuliskan kesimpulan dari hasil yang diperoleh. Selain itu, siswa impulsif juga bekerja secara tergesa-gesa sehingga tidak mengecek kembali hasil pada setiap langkah yang dilakukan dalam pemecahan masalah dan tidak mampu menemukan alternatif lain untuk menyelesaikan masalah. Hal ini sesuai dengan pendapat Muniroh et al. yang mengatakan bahwa siswa impulsif mengumpulkan hasil jawban tes pemecahan masalah setelah selesai dikerjkan tanpa melakukan pengecekan kembali jawabannya, sehingga jawaban siswa impulsif cenderung kurang tepat (Muniroh et al., 2020).

\subsection{Perbedaan Kemampuan Pemecahan Masalah Matematika Siswa Reflektif dan Impulsif}

Setelah meninjau tahapan pemecahan masalah dari siswa yang bergaya kognitif reflektif dan impulsif dalam menyelesaikan soal pemecahan masalah dapat dilihat dari indikator yang dipenuhi oleh masing-masing gaya kognitif dari mulai tahap memahami masalah, memikirkan rencana, melaksanakan rencana, dan melihat kembali dapat dikatakan bahwa siswa reflektif lebih baik dibandingkan dengan siswa impulsif. Hal ini disebabkan karena siswa yang bergaya kognitif reflektif cenderung menggunakan lebih banyak waktu dan lebih teliti/cermat dalam menyelesaikan soal pemecahan masalah. Sesuai dengan pendapat Kagan dalam Stannard yang mengatakan bahwa siswa reflektif sangat berhati-hati dan memanfaatkan semua alternatif. Kemudian waktu yang digunakan relatif lama dalam merespon tetapi kesalahan yang dibuat relatif kecil (Stannard, 2003).

Sedangkan siswa impulsif menggunakan waktu yang relatif cepat dalam merespon, tetapi cenderung membuat kesalahan karena siswa impulsif tidak memanfaatkan semua alternatif. Hal ini sesuai dengan pendapat Kagan dalam Stannard yang mengemukakan bahwa orang yang memiliki gaya kognitif impulsif menggunakan alternatif-alternatif secara singkat dan cepat untuk menyeleksi sesuatu (Stannard, 2003). Pada siswa impulsif sering melewatkan tahapan memikirkan rencana yaitu salah satu siswa impulsif tidak menuliskan rencana penyelesaian dan tahapan melihat kembali yaitu terdapat siswa impulsif yang tidak menuliskan kesimpulan dan tidak memeriksa kebenaran jawaban yang diperoleh. Berdasarkan uraian tersebut, didapatkan perbedaan siswa reflektif dan siswa impulsif adalah sebagai berikut. 
Tabel 4. Perbedaan Siswa Reflektif dan Impulsif

\begin{tabular}{|c|c|c|c|}
\hline No. & $\begin{array}{l}\text { Pemecahan } \\
\text { Masalah }\end{array}$ & Siswa Reflektif & Siswa Impulsif \\
\hline 1. & $\begin{array}{l}\text { Memahami } \\
\text { masalah }\end{array}$ & $\begin{array}{l}\text { a. Mampu menuliskan apa } \\
\text { yang diketahui dan } \\
\text { ditanyakan dengan benar } \\
\text { dan lengkap. } \\
\text { b. Mampu mengungkapkan } \\
\text { soal dengan kalimat } \\
\text { sendiri. }\end{array}$ & $\begin{array}{l}\text { a. Mampu menuliskan apa } \\
\text { yang diketahui dan } \\
\text { ditanya dari soal dengan } \\
\text { benar namun kurang } \\
\text { lengkap. } \\
\text { b. Mampu mengungkapkan } \\
\text { soal dengan bahasa soal } \\
\text { atau dengan membaca } \\
\text { ulang soal. }\end{array}$ \\
\hline 2. & $\begin{array}{l}\text { Memikirkan } \\
\text { rencana }\end{array}$ & $\begin{array}{l}\text { Mampu mengaitkan antara } \\
\text { hal-hal yang diketahui, hal- } \\
\text { hal yang belum diketahui } \\
\text { dan apa yang ditanyakan } \\
\text { pada soal dan } \\
\text { menuliskannya. }\end{array}$ & $\begin{array}{lr}\text { Mampu mengaitkan } \\
\text { antara hal-hal yang } \\
\text { diketahui, hal-hal yang } \\
\text { belum diketahui dan apa } \\
\text { yang ditanyakan pada soal } \\
\text { tetapi tidak } \\
\text { menuliskannya. }\end{array}$ \\
\hline 3. & $\begin{array}{l}\text { Melaksanakan } \\
\text { rencana }\end{array}$ & $\begin{array}{l}\text { a. Teliti dalam melakukan } \\
\text { perhitungan dalam } \\
\text { menyelesaikan masalah. } \\
\text { b. Membutuhkan waktu } \\
\text { relatif lama dalam } \\
\text { menyelesaikan masalah. }\end{array}$ & $\begin{array}{l}\text { a. Kurang teliti dalam } \\
\text { melakukan perhitungan } \\
\text { dalam menyelesaikan } \\
\text { masalah. } \\
\text { b. Membutuhkan waktu } \\
\text { relatif cepat dalam } \\
\text { menyelesaikan masalah. }\end{array}$ \\
\hline 4. & $\begin{array}{l}\text { Melihat } \\
\text { kembali }\end{array}$ & $\begin{array}{l}\text { Melakukan pengecekan } \\
\text { kembali terhadap jawaban } \\
\text { yang diperoleh namun } \\
\text { dengan cara yang sama. }\end{array}$ & $\begin{array}{l}\text { Tidak melakukan } \\
\text { pengecekan kembali } \\
\text { terhadap jawaban yang } \\
\text { diperoleh. }\end{array}$ \\
\hline
\end{tabular}

\section{SIMPULAN}

Berdasarkan hasil penelitian dan pembahasan mengenai kemampuan pemecahan masalah matematika siswa ditinjau dari gaya kognitif reflektif dan impulsif dapat disimpulkan bahwa siswa reflektif mampu memahami masalah, memikirkan rencana , dan melaksanakan rencana dengan baik dan benar. Tahap akhir yaitu tahap melihat kembali siswa reflektif hanya menuliskan kesimpulan yang diperoleh namun tidak melakukan pengecekan jawaban. Akan tetapi kedua siswa reflektif mampu menjelaskan bagaimana cara mereka memeriksa kembali jawaban mereka pada saat wawancara dengan bahasa mereka sendiri. Sedangkan siswa impulsif pada tahap memahami masalah yaitu mampu memahami apa yang diketahui dan ditanyakan dari soal, namun pada tahap memikirkan rencana, siswa impulsif kurang tepat dalam menuliskan aturan matematika (rumus) dan terdapat siswa impulsif yang tidak menuliskan rencana pada tahap tersebut.

Pada tahap melaksanakan rencana siswa impulsif belum mampu melaksanakannya dengan baik yaitu siswa impulsif tidak cermat atau teliti dalam menyelesaikan masalah. Hal ini disebabkan oleh kesalahan siswa pada saat mengerjakan soal pemecahan masalah, kedua siswa impulsif kurang tepat dalam menyelesaikan permasalahan, 
sehingga jawaban yang diberikan cenderung salah. Kesalahan ini disebabkan gaya kognitif siswa yang cenderung cepat dalam menyelesaikan soal namun salah dalam mendapatkan hasil akhir. Pada tahap melihat kembali siswa impulsif hanya mampu menuliskan kesimpulan tetapi kurang tepat karena hasil yang diperoleh salah, dan terdapat siswa impulsif yang tidak menuliskan kesimpulan dari hasil yang diperoleh. Selain itu, siswa impulsif juga tidak mampu menjelaskan bagaimana cara memeriksa kembali jawaban mereka pada saat wawancara.

\section{REFERENSI}

Akbar, A., \& Haidar, I. (2019). Profil literasi matematika ditinjau dari gaya kognitif. Prosiding seminar nasional pendidikan matematika II (SNPMAT II). Kendari: Universitas Halu Oleo Press.

Faradillah, A. (2014). The profile of junior high school students reasoning in solving mathematics open-ended problem according to reflective-impulsive cognitive styles. Proceeding of International Conference on Research, Implementation and Education of Mathematics and Sciences, 113-120.

Hayuningrat, S., \& Listiawan, T. (2018). Proses berpikir siswa dengan gaya kognitif reflektif dalam memecahkan masalah matematika generalisasi pola. Jurnal Elemen, 4(2): 183-196.

Kemendikbud. (2014). Permendikbud Nomor 58 Tahun 2014.

Muniroh, L., Sugiyanti, \& Nursyahidah, F. (2020). Analisis kemampuan pemecahan masalah matematika siswa dalam menyelesaikan soal cerita ditinjau dari gaya kognitif impulsif pada masa pandemi covid-19. SENATIK, 352-359.

Nasriadi, A. (2015). Profil pemecahan masalah matematika siswa smp ditinjau dari gaya kognitif reflektif dan impulsif. Jurnal Ilmiah Pendidikan Matematika, 2(2), 1-27.

NCTM. (2000). Principles and standars for school mathematics. Reston, VA: NCTM.

Puspita, A. Y. A., \& Wijayanti, P. (2016). Profil pemecahan masalah matematika siswa pada materi segiempat ditinjau dari gaya kognitif reflektif dan impulsif. Jurnal MATHEdunesa, 3(5): 17-27.

Soeprianto, H., Prayitno, S., Hamdani, D., Apsari, A. R., \& Wulandari, P. N. (2021). Desain pembinaan bakat matematika siswa smp untuk persiapan menghadapi kompetensi sains nasional. Jurnal abdimas (Journal of Community Service): Sasambo, 3(1): 32-40. https://doi.org/10.36312/sasambo.v3i1.391.

Stannard, P. L. (2003). Cognitive styles: a review of the major theories and their application to information seeking in virtual environments. Journal of the American Society for Information Science, 40(1): 54-66.

Sugiyono. (2015). Metode penelitian \& pengembangan. Yogyakarta: Alfabeta.

Susanto, H. A. (2015). Pemahaman pemecahan masalah berdasar gaya kognitif. Yogyakarta: Deepublish.

Turmuzi, M., \& Hayati, L. (2012). Telaah kurikulum matematika. Mataram: Arga Puji Press.

Wahyuningsih, S., Sani, A., \& Suia, M. (2019). Analisis proses berpikir siswa smp dalam memecahkan masalah matematik ditinjau dari gaya kognitif dan gender. Jurnal Pembelajaran Berpikir Matematika, 4(1): 121-132.

Warli. (2013). Kreativitas siswa smp yang bergaya kognitif reflektif atau impulsif dalam memecahkan masalah geometri. Jurnal Pendidikan dan Pembelajaran, 20(2): 190-201. 